Omni-Akuatika, 14 (1): 69-76, 2018
ISSN: 1858-3873 print / 2476-9347 online
Research Article
journal homepage: http://ojs.omniakuatika.net

\title{
Chlorophyll-a Distribution and Its Relation with Current Pattern in Northern Waters of Central Java
}

\author{
Bella Shabrina $^{1^{\star}}$, Lilik Maslukah ${ }^{1}$, Sri Yulina Wulandari ${ }^{1}$ \\ ${ }^{1}$ Department of Oceanography, Faculty of Fisheries and Marine Sciences, \\ Diponegoro University, Semarang, Indonesia \\ "Corresponding author: bellashabrinaz@gmail.com
}

Received 14 September 2017; Accepted 13 May 2018; Available online 31 May 2018

\begin{abstract}
Water fertility will determine the ammount of aquatic biotas (especially fish) that can live in the area. The high concentration of chlorophyll-a will show that water productivity in the area is high and fertile. The availability of chlorophyll-a in the waters is affected by oceanographic condition. One of them is the current pattern. The purpose of this study is to determine the distribution of chlorophyll-a spatially and temporally and its relation with current patterns in the northern waters of Central Java. The data that used in this research includes: chlorophyll-a data that obtained from level III Aqua MODIS imagery, current model data was obtained from MyOcean.eu, rainfall data, and sea surface temperature data that also obtained from Aqua MODIS satellite imagery. Sampling was done by purpossive sampling method. Distribution of chlorophyll-a that happened in Northern Waters of Central Java fluctuates every month. The largest concentration of chlorophyll-a was located close to the coastal area. The largest concentration of chlorophyll-a happened in June 2015 and 2016. Current pattern that happened in 2015 - 2016 changed every month and it was affecting the distribution of chlorophyll-a. However, the distribution of chlorophyll-a was not fully affected by the current pattern. There were several other factors such as river runoff and intensity of sunlight that could affect the chlorophyll-a distribution.
\end{abstract}

Keywords : chlorophyll-a, phytoplankton, distribution, current, runoff

\section{Introduction}

Northern Waters of Central Java are Indonesian marine that located in Java Sea. In this area, there is a wind patterm system called Australia - Asia monsoon wind. The wind circulation highly influences the current pattern in Northern Waters of Java. Therefore the current pattern in Northern waters of Java varies every season following the wind pattern (Wyrtki, 1961; Sofian et al., 2007).

Phytoplankton is important for providing the foundation for aquatic food chains (Reynolds, 1984; Vargas et al., 2006).Fertility of the waters can be seen by the availability of chlorophyll-a and nutrient in those area (Bucci et al., 2012; Wu et al., 2014). Photosynthesis pigment (especially Chlorophyll-a) shows the biomass of phytoplankton in the waters. Chlorophyll-a is a pigment that can be found in phytoplankton and directly involved in photosynthesis process (Pugesehan, 2010; Bucci et al., 2012).

Velocity and direction of the wind that occur in every season will affect the sea dynamics. Sea dynamics occur due to several oceanographic factors (Syahdan et al., 2014). One of them is the sea current. Current has important role for the hydrodynamics processes in the ocean. Sea current will influence the water mass movement. Water mass movement then will also influence the distribution of chlorophyll-a and the others materials (Sugianto et al., 2017).

The results of Gaol and Sadhotomo (2007) showed thatin the western part of the Java Sea, the distribution of chlorophyll-a is relatively the same in both seasons, but in the eastern part of the Java Sea, the chl-a 
concentration increases during the southeast monsoon. Fertility of the waters will determine the ammount of aquatic biotas that can live in the waters (Pugesehan, 2010). By knowing the location of water fertility, fish finding for fisherman will be easier. Indonesia is a country with most of the population is a fisherman (Retnowati, 2011). Therefore, the research of chlorophyll-a distribution that affected by the sea current is necessary. The purpose of this research is to know the distribution of chlorophyll-a spatially and temporally in relation with current pattern in Northern Waters of Central Java.

\section{Material and Methods}

The methods that used for analysis is descriptive methods with quanitative approach. Research location was in the Northern Waters of Central Java which was limited by $5.5 \mathrm{O}$ $7.5 \mathrm{OS}$ and $108.8 \mathrm{O}-111.8 \mathrm{O} \mathrm{E}$ (Figure 1). The data that used for this research includes chlorophyll-a data that obtained from Level III Aqua MODIS imagery, current model data was obtained from MyOcean.eu, rainfall data, and sea surface temperature data that also obtained from Aqua MODIS satellite imagery. Sampling was done by purpossive sampling method.

\section{Data collecting methods}

Chlorophyll-a data was downloaded in NASA's site http://oceancolor.gsfc.nasa.gov in ${ }^{*}$ nc format. Data that used for this research was Aqua MODIS level III imagery, that had been corrected geometrically and composited monthly. Satellite imageries used are imageries with good conditions that contained in the month March - August 2015 and 2016. Then the imagerysatellite was processed with SeaDAS ArcGIS 10.3 software (Gaol, 2014). Aqua MODIS satellite imagery, has a better coefficient determination than Terra MODIS satellite imagery. Aqua MODIS determination coefficient is $77.57 \%$ while Terra MODIS is $72.34 \%$ (Ratnasari, 2016).

Current model March - August 2015 and 2016 period data was obtained from a website http://MyOcean.eu. Data that used was current model with a depth of $0-1$ meter and resolution $1 / 12$ degree. This data is the result of modelling using NEMO 3.1 (Nucleus for European Models of the Ocean) and LIM2 (Louvain Sea Ice Model 2). The data input is an atmospheric force obtained from ECMWF atmospheric data, calculations and forecasting methods using empirical formulas. Rainfall data was obtained from a website http://www7.ncdc.noaa.gov/cdo/dataproduct.

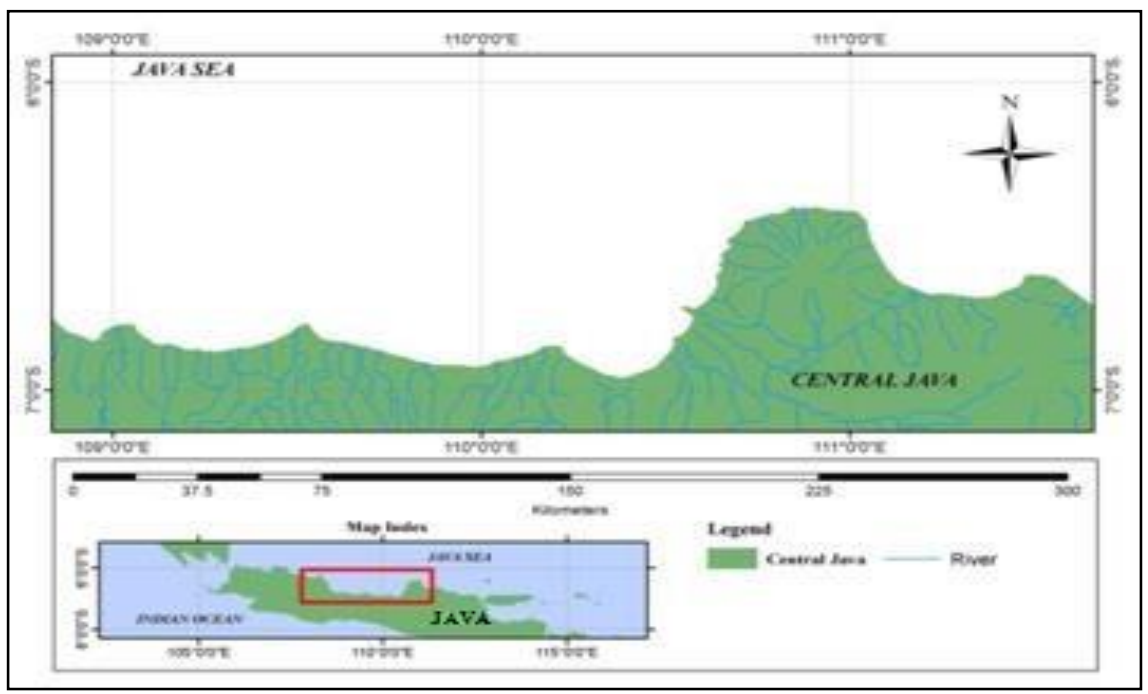

Figure 1. Research location map 


\section{Results and Discussion}

The results of this study include spatial and temporal chlorophyll-a distribution, Sea current data, sea surface temperature, and rainfall data.

\section{Spatial chlorophyll-a distribution}

Spatial distribution data of chlorophyll-a obtained from Aqua MODIS level III imagery that had been composited monthly and displayed in map form. The map that used for the result is a map that overlaid with current direction and velocity data. Chlorophyll-a distribution map in 2015 - 2016 displayed in Figure 4.

Temporal chlorophyll-a distribution

Temporal chlorophyll-a graphic in March - August in 2015 and 2016 shown in Figure 2.

Current's direction and velocity

Direction and Velocity Graphic of Nothern Central Java Waters shown in Figure 3 and Figure 5.

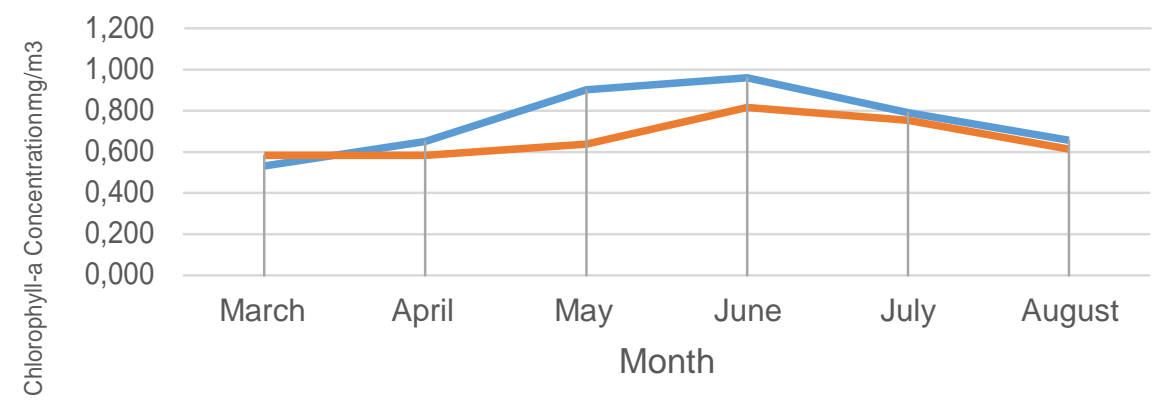

Figure 2. Chlorophyll-a concentration in March - August 2015 and 2016

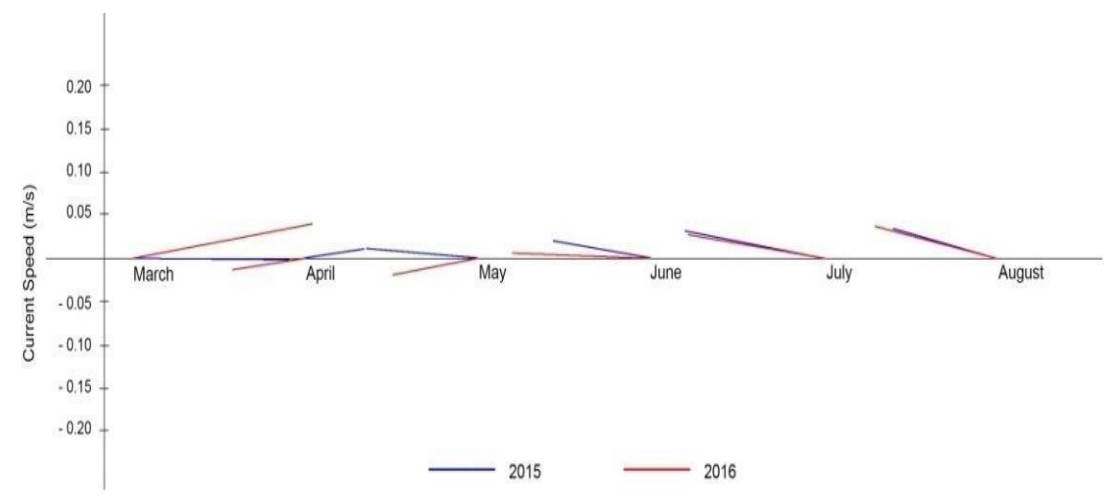

Figure 3. Direction and velocity of Nothern Central Java Waters in March- August 2016

Based on graphic in Figure 3, it shows at current pattern in March - August 2015 and 2016 is not the same. The graphic is also shows that current velocity component that more dominant in Northern Waters of Central Java waters is the $\mathrm{u}$ (zonal) component. It appears that the current component $u$ has a larger average velocity as compared to the current component $v$.
The negative component of $u$ and $v$ component indicates that the current leads to South (negative $\mathrm{v}$ component) and West (negative u component) direction. Therefore, we can see that in March, the positive $u$ component shows that the current leads to East direction. The current leads to West direction from May to August. 
Sea surface temperature

Sea surface temperature data obtained from Aqua MODIS level III Imagery that had been composited monthly and displayed in table form average value of sea surface temperature (Table 1). High temperature indicates that the area has high intensity of sunlight. Light intensity will affect chlorophyll-a concentration (Wu et al., 2014).

Rainfall

Rainfall data is presented in Table 2.

Table 1. Average Value of Sea Surface Temperature March - August 2015 and 2016

\begin{tabular}{ccc}
\hline Month & & Sea Surface Temperature $\left({ }^{\circ} \mathrm{C}\right)$ \\
\cline { 2 - 3 } & 2015 & 2016 \\
\hline March & 30.00 & 30.59 \\
April & 30.61 & 30.72 \\
May & 29.34 & 30.89 \\
June & 29.38 & 30.54 \\
July & 28.17 & 29.80 \\
August & 28.11 & 29.53 \\
\hline
\end{tabular}

Table 2. Rainfall Data Table March - August 2015 and 2016

\begin{tabular}{ccc}
\hline \multirow{2}{*}{ Month } & \multicolumn{2}{c}{ Rainfall $(\mathrm{cm})$} \\
\cline { 2 - 3 } & 2015 & 2016 \\
\hline March & 185.67 & 56.89 \\
April & 264.16 & 241.81 \\
May & 88.39 & 70.61 \\
June & 77.47 & 67.31 \\
July & 0.00 & 71.37 \\
August & 11.93 & 138.43 \\
\hline
\end{tabular}

Based on existing rainfal data, the highest rainfall occured in April both in 2015 and 2016. High concentration of chlorophyll-a was affected by the Rainfall rate that occurred in the area (Nababan, 2009).

Based on Figure 4, we can see the differences between the Northern and Southern spatial chlorophyll-a phenomenon. Higher chlorophyll-a availability generally located in the Southern area near the coast. This phenomenon might be caused by the runoff and Nutrient from the river. Increased concentrations of $\mathrm{N}$ and $\mathrm{P}$ in waters are strongly influenced by the presence of rivers that carry the mass of water from the land (runoff) and their fluctuations are affected by the seasons (Maslukah, 2016). Runoff process depends on the rainfall rate that occurs in the area. Higher rainfall rate will bring more runoff with nutrients to the sea (Nababan, 2012). The greatest rainfall rate, occured in March, April in 2015 and April, August in 2016 (Table 1). This Indicates that the chlorophyll-a concentration might be affected by runoff. Thus, simultaneous rises in nutrient contributed to increases in chlorophyll-avalues (Kideys et al., 2008;
Kopelevich et al., 2008). In addition to runoff, the concentration of chlorophyll-a is also influenced by other factors such as sunlight intensity.

Compared to research by Ratnasari (2016), chlorophyll-a seen higher in coastal area. This might caused by runoff and nutrient that carried from the land. Nitrate that carried by runoff in Jepara area in June and August 2016 ranges between 3.853 - 50.687 tons/month while phosphate ranges between $0.604-4.001$ tons/month (Maslukah, 2016).

Based on the graph in Figure 3, the concentration of chlorophyll-a in the sea is seen high in May - July2015 - 2016. This is allegedly happen due to the influence of high intensity of sunlight occuring in those months, as evidenced by the high sea surface temperature on the month (Table 1). The increased intensity of sunlight causes the primary productivity to also increase and might be related to the increase amount of phytoplankton cells at sea surface which also has chlorophyll-a (Tasak, 2015). The results of the concentration of chlorophyll a in the Java Sea are very flutuative. The eastern Java Sea shows its maximum 
concentration in April and October minimum (Syahdan et al., 2014).

The Current that occurs in the northern waters of Central Java, is the current generated by the Asia - Australia monsson system (Wyrtki, 1961). According to Figure 4, it can be seen that in the transitional season 1 (March May) the current that originally directed towards the East, slowly moved towards the West. In the East Monsoon (June - August), the current moved Westward in accordance with the East Monsoon wind that happened in the season. Current pattern that occured in March - August 2015 and 2016 generally follows the monsson wind pattern. That occured in the trasitional season I and East season. This can be seen from the changing drection of current pattern from East to West during the trasitional season I.

The current, however, does not affect fully to the distribution of chlorophyll-a. Distribution of chlorophyll-a is more inflluenced by the intensity of sunlight and runoff that occur (Jamshidi and Abu Bakar, 2011). Thus the distribution of chlorophyll-a in the Northern waters of Central Java is not fully influenced by the current pattern.

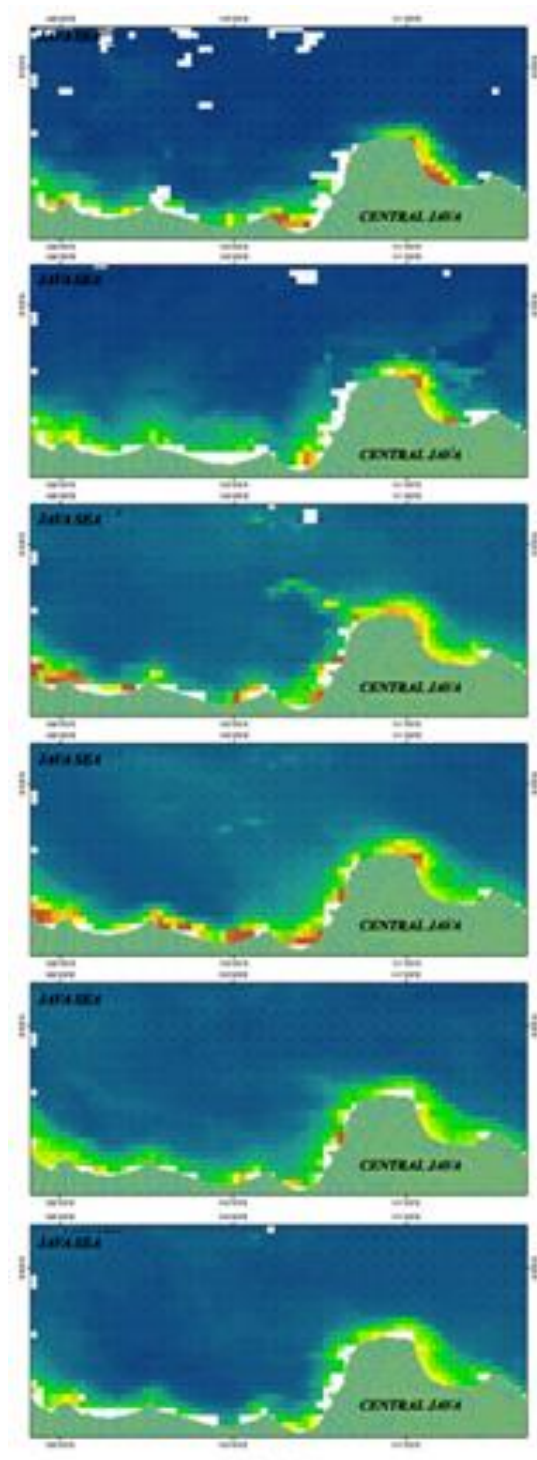

2015
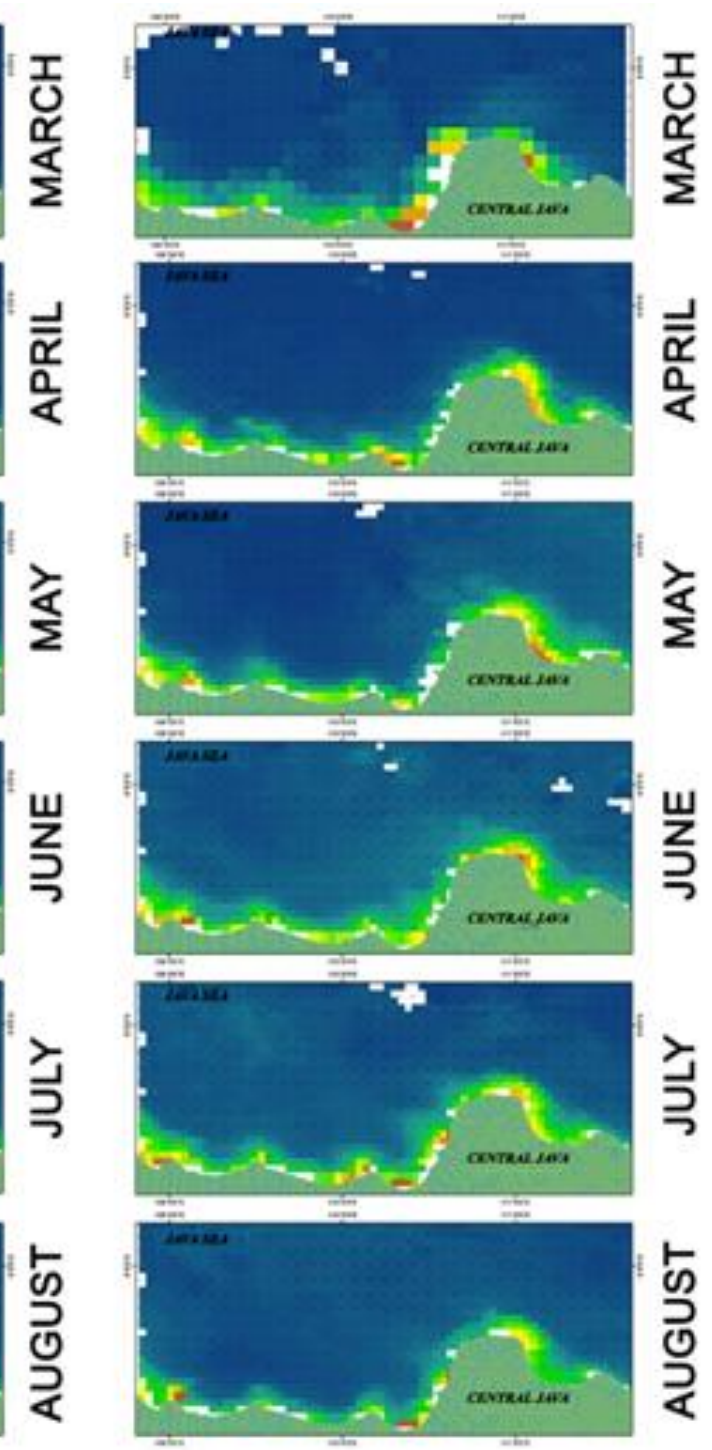

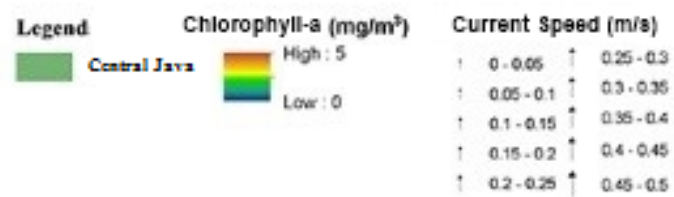

Figure 4. Spatial and temporal chlorophyll-a and current distribution 


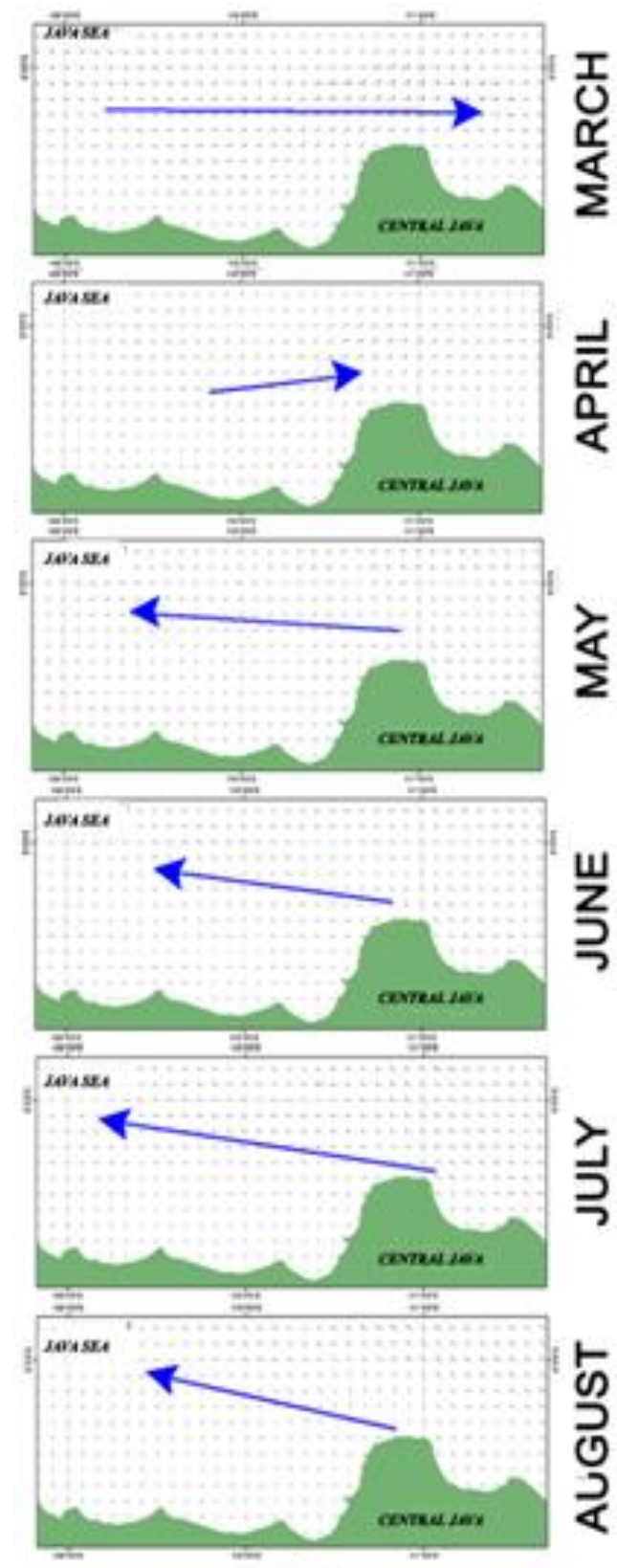

2015
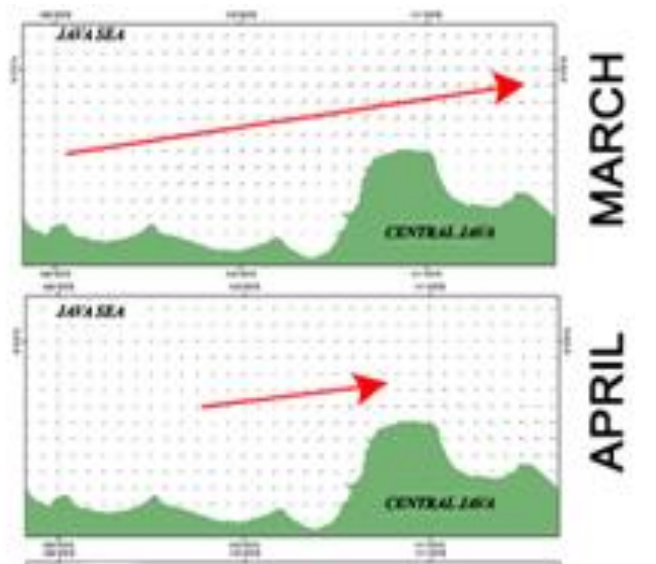

$\frac{\vec{\gamma}}{\frac{\hat{\alpha}}{\alpha}}$
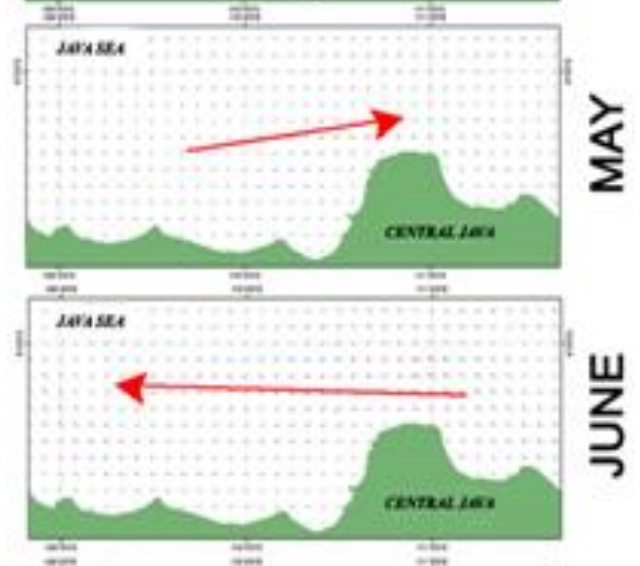

岂

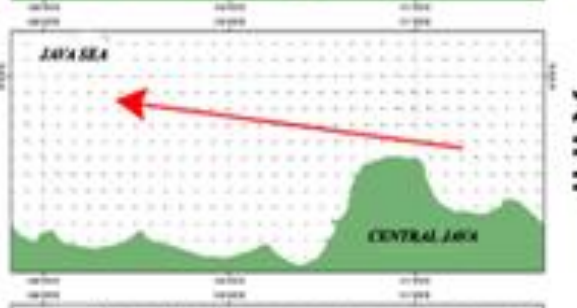

$\frac{7}{3}$

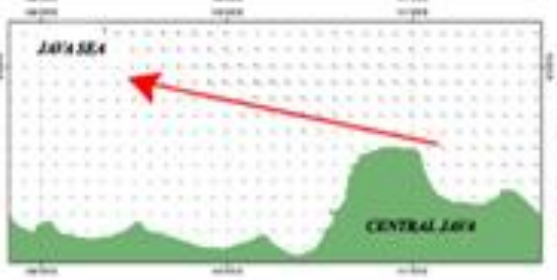

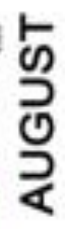

\section{6}

Figure 5. Current vector in northern waters of Central Java

\section{Conclusion}

The distribution pattern of chlorophyll-a in the Northern waters of Central Java is not fully influenced by the seasonal current pattern occuring in the region. In March - May, the largest chlorophyll-a concentration was distributed to the East while in June - August the largest chlorophyll-a concentration was distributed to the West. The distribution of chlorophyll-a occuring in the Northern waters of Central Java not only influenced by the current pattern but also influenced by the intensity of sunlight, river runoff, and nutrients that occur in the region. 


\section{References}

Bucci, A. F., Ciotti, Á.M., Pollery, R.C.G., Carvalho, R. de., Albuquerque, H.C. de., Simões, L.T.S. 2012. Temporal variability of chlorophyll-ain the São Vicente Estuary. Brazilian Journal Of Oceanography 60(4), 485-499.

Gaol, J.L., Sadhotomo, B. 2007. Karakteristik dan variabilitas parameter-parameter oseonografi Laut Jawa hubungannya dengan distribusi hasil tangkapan ikan. Jurnal Penelitian Perikanan Indonesia 13(3), 201-211.

Gaol, J L., Wudianto, Pasaribu, B.P., Manurung, D., Endriani, R., 2014. The Fluctuation of chlorophyll-a concentration derived from satellite imageryry and catch of oily sardine (Sardinella Lemuru) in Bali Strait. Remote Sensing and Earth Sciences 1(1), 24-30.

Jamshidi, S., Abu Bakar, N. B. 2011. Seasonal variations in temperature, salinity and density in 15 the southern coastal waters of the Caspian Sea. Oceanology, in press.

Kideys, A. E., Roohi, A., Eker-Develi, E., Melin, F., Beare, D. 2008. Increased chlorophyll levelsin the Southern Caspian Sea following an invasion of jellyfish, Research Letters in Ecology, 4 pages, Hindawi Publishing Corporation.

Kopelevich, O. V., Burenkov, V. I., Sheberstov, S. V. 2008. Biodiversity. Case studies of opticalremote sensing in the Barents Sea, Black Sea and Caspian Sea, in: Remote Sensing of the European Seas. Springer part 2, 53-66.

Maslukah, L., Wulandari, S Y., Prasetyawan, I. B., 2017. Kontribusi N dan P dari Sungai Serang dan Wisoke Perairan Jepara. Proceeding Seminar Nasional Hasil - Hasil Penelitian Perikanan dan Kelautan Ke-6 Fakultas Perikanan dan IImu Kelautan Universitas Diponegoro, $183-191$.

Nababan, B., Zulkarnaen, D., Gaol J.L. 2009. Variabilitas Konsentrasi klorofil-a di Perairan Utara Sumbawa Berdasarkan Data Satelit SeaWiFS.
Jurnal IImu dan Teknologi Kelautan Tropis 1 (2), 72-83.

Nababan B., Simmamora, K. 2012. Variability of chlorophyll-a concentration and sea surface temperature of Natuna Waters. Jurnal Ilmu dan Teknologi Kelautan Tropis 4(1), 121-134.

Pugesehan, D. 2010. Analisis klorofil-a fitoplankton (produktivitas primer) di peraian Pantai Natsepa Kabupaten Maluku Tengah. Jurnal Agroforestri $\mathrm{V}(4), 272-274$

Ratnasari., Putra, R. D. P., Idris, F. 2016. Pemetaan klorofil-a di perairan Laut Cina Selatan menggunakan citra satelit aqua. Jurnal Umrah. Universitas Maritim Raja Ali.

Retnowati, E. 2011. Nelayan Indonesia dalam pusaran kemiskinan struktural (Perspektif Sosial, Ekonomi, dan Hukum). Jurnal Perspektif XVI Universitas Wijaya Kusuma, Surabaya.

Reynolds, C.S., 1984. The Ecology of freshwater phytoplankton. Cambridge University Press, London.

Sofian, I., Kozai, K., Ohsawa, T. 2007. Investigation on the relationship between wind-induced transport and mean sea level in the Java Sea using an oceanic general circulation model. UMITOSORA, in press.

Sugianto,D.N., Rochaddi, B., Wulandari, S.Y., Subardjo, P., Suryoputro, A. N. D., Atmodjo, W., Satriadi, A., 2017. Current characteristics in Demak waters based on acoustic measurement. International Journal of Civil Engineering and Technology (IJCIET) 8 (9), 749-760.

Syahdan, M., Atmadipoera, A.S., Susilo, S. B., Gaol, J.L. 2014. Variability of surface chlorophyll-a in the Makassar Strait - Java Sea, Indonesia. International Journal of Sciences: Basic and Applied Research (IJSBAR) 14 (2), 103-116

Tasak, A.R., Kawaroe, M., Prartono, T., 2015. Keterkaitan intensitas cahaya dan kelimpahan dinoflagellate di Pulau 
Samanola Makasar. Jurnal IImu Kelautan IPB 20 (2), 113-120.

Vargas. C.A., Escribano, R., Poulet, S. 2006. Phytoplankton food quality determines time windows for successful zooplankton reproductive pulses. Ecology (8), 2992-2999.

Wu., Z., He, H., Cai, Y., Zhang, L., Chen. Y. 2014. Spatial distribution of chlorophyll a and its relationship with the environment during summer in Lake Poyang : a Yangtze-connected lake. Journal of Hydrologia 732, 6170.

Wyrtki, K. 1961. Physical oceanography of the Southeast Asian Waters. The University of California Scripps Institution of Oceanography, La Jolla, California. 